\title{
Oneiric Metaphor in Film Theory
}

\author{
By Laura Rascaroli
}

Fall 2002 Issue of KINEMA

\section{LIKE A DREAM. A CRITICAL HISTORY OF THE ONEIRIC METAPHOR IN FILM THE- ORY}

I know it's a cliché to say that films are like dreams -- like a collective unconscious,' Terry began, 'but I was thinking that nobody's ever really followed the idea through. There are different sorts of dreams, aren't there? And so obviously there are horror movies, which are like nightmares, and then there are dirty movies like Deep Throat and Emmanuelle, which are like wet dreams... Then there are remakes, and stories which keep getting told again and again, and those are like recurring dreams. And there are consoling, visionary dreams, like Lost Horizon or The Wizard of Oz. But when a film gets lost, and it's never been shown, and the print goes missing and nobody's ever seen it, that's the most beautiful kind of dream of all. Because that's the kind of dream that might just have been the best one you've ever had in your life, only it slips from your mind just as you're waking up, and a few seconds later you can't remember a thing about it.

(Jonathan Coe, The House of Sleep)

The couple Cinema \& Psychoanalysis was endorsed in the Seventies chiefly on the basis of the analogies that were said to exist between film and dream. The celebrated Issue 23 of Communications (1975) sealed the union in the name of semiology: linguistics and psychoanalysis, in fact -- according to Christian Metz -- not only were both concerned with the symbolic, but were also the only two sciences whose immediate and only object of study was the act of signification itself; for this reason they seemed able to lead to 'a relatively autonomous science of cinema' -- a semiology of cinema. ${ }^{(1)}$

The outcome of this adventure is not completely clear. The introduction of semiotics has indisputably been one of the most meaningful turning points in film theory, as it revolutionised our conception of text and textual analysis; at the same time, the wishful goal of reaching 'a relatively autonomous science of cinema' does not excite anybody anymore. What should be said, then, of the convergence of cinema and psychoanalysis? In his Theories of Cinema, Francesco Casetti identified two main strands of the psychoanalytical approach to the study of cinema: first, the analyses which tend to uncover the latent content of a film, read as symptom or dream, and used as a basis to analyse the filmmaker's unconscious mind; second, the psychoanalytical investigation of certain aspects of film and the cinematic apparatus, for instance the psychological mechanisms which are at play in the viewing process. ${ }^{(2)}$ The goal of this type of investigation is a metapsychology of the spectator, such as that outlined by Metz in Le signifiant imaginaire.

The first of these two main strands was destined to attract all the obvious objections traditionally raised against the 'biographic' psychoanalytical critique -- an approach inaugurated by Freud himself, and taken up in particular by Marie Bonaparte in her work on Edgar Allan Poe. ${ }^{(3)}$ In particular, many critics stressed that the absence of the typical conditions of analysis results in the impossibility of transfer, free associations and the return of repressed contents. ${ }^{(4)}$ It is much more complex to evaluate the outcome of the second strand of the psychoanalytical approach, with its important ramifications, such as those linked to feminist film theory and spectatorship theory. What interests me here, though, is to investigate and assess the development and outcome of the earliest idea from which the whole adventure of the couple Cinema \& Psychoanalysis derives: the supposed analogies existing between film and dream. The dream is one of the most persistent metaphors in both classical and modern film theory, and is hence worthy of organic assessment.

\section{History of a metaphor}

The dream metaphor has a long history in film theory. It begins as early as the birth of cinema, with the famous dispute on the contrast between cinema as a (perfect) system of reproduction of reality on the one hand, and as magic and dream on the other. In Esthetique du cinéma (1957), Henri Agel listed the early theorists who recognised the oneiric nature of cinema, beginning with Ricciotto Canudo (1879-1923), who urged filmmakers to transform reality in conformity to their inner dream; and ending with Jean Epstein (1897-1953), who found in film a perfect affinity with dreams. ${ }^{(5)}$ 
Many contributions drawing on psychology, aesthetics and sociology have been relevant to the establishment of the dream metaphor. The first major one is Edgar Morin's Le cinéma ou l'homme imaginaire (1956). Morin stressed that dreams and films are perceived objectively by dreamers and spectators respectively, but that, at the same time, a strong dose of subjectivity intervenes in both cases. In the filmic image, as in dreams, we do not perceive a real presence, but the double of a presence. Nevertheless, Morin recognised two characteristics that distinguish the film from dreams: its materiality, and the necessary presence of an original physical object. This difference, though, is reduced for Morin by the oneiric quality of the lighting and music in cinema.

Also Jean Mitry, a few years later, in the first volume of his Esthétique et psychologie du cinéma (1963), recognised the importance of the materiality of film strip and screen, but also considered that the film offers itself to the spectator as an image detached from its physical supports and independent of them. For the author, this fact associates film to the mental image, which is characterised by similar features; and simultaneously differentiates it from the perceptive image that, on the contrary, is not separated from the objects, and even identifies with them. Even so, the filmic image for Mitry is different from the mental image inasmuch as it is concrete, objective and situated 'somewhere'. Between mental image and oneiric image, thus, there is a difference in grade or intensity, not in nature. Whereas mental images oppose our normal perception of the world, oneiric images replace it, becoming a pseudo-reality in which we believe completely. The filmic image, therefore, is related to the mental image by its rapport with its material supports, but is more similar to the oneiric image because, like the latter, it replaces the real. Spectators, though, according to Mitry have a possibility that is denied to dreamers: to refuse the complete participation and involvement in what they see.

Morin and Mitry's comparisons of the psychological and perceptive qualities of oneiric image and filmic image formed one of the solid bases on which the metaphor was constructed. The comparison between spectator and dreamer became the most widely quoted and important similarity between film and dream. This comparison was grounded in the descriptions of the often-bizarre experiments of cinema going to be found in the Surrealists' writings. In particular, Breton wrote that each spectator, before becoming subjugated by the filmic fiction, goes through a critical stage that can be compared to the one between being awake and falling asleep. ${ }^{(6)}$ According to René Clair, then, during the projection the spectators, overwhelmed by the music and shadows on the screen, are almost in a dreamlike state. ${ }^{(7)}$

Morin and Mitry also described the spectatorial condition as a para-oneiric state. For the former, this condition is produced by several factors: the darkness of the auditorium; the comfort of the chair, which induces the spectator to relax and fantasise; the passivity and absence of movement, inviting a psychic and emotive participation. In such a regressive state, according to Morin, the spectator increases the normal psychic mechanisms of projection and identification, and somehow fulfils her or his most intimate desires. For Mitry, the spectatorial state lies somewhere between dream and daydream. In fact, it is similar to dreams in that the imaginary replaces the real; and it resembles daydreaming because the spectator always preserves a certain consciousness.

Many of these arguments also recur in the literature that is more closely linked to the couple Cinema \& Psychoanalysis, and which here particularly interests me. I refer to the scholars -- both psychoanalysts and film theorists -- who directly used psychoanalytical tools to discuss the relationship between film and dreams. As mentioned above, the couple was sanctioned in 1975, but contributions started much earlier, in the mid 1940s. Before I begin to consider them, it should be said that the references to dreamlike cinema are infinite. Many interesting ones can be found, not surprisingly, in the literature on the avant-garde movements, such as Ado Kyrou's Le surréalisme au cinéma (1963) and Jean Mitry's Le cinéma experimental. Historie et perspectives (1974). ${ }^{(8)}$ Kyrou has recognised traces of oneirism not only in experimental cinema, but also in the musical, thriller, horror, and in much comic cinema (for instance, the Marx Brothers, Helzapoppin, and Jerry Lewis). ${ }^{(9)}$ For his part, Morin has described James Bond as a hyper-oneiric hero, a true dreamlike creature; ${ }^{(10)}$ and Odile Bächler has asserted that the traditional link between sleep, dream and trip projects an oneiric quality on those Westerns based on a stagecoach trip. ${ }^{(11)}$

\section{The dream is like a film}

The idea of a connection between film and dreams seems to be grounded in Freud's theories. The father 
of psychoanalysis stated that dreams dramatise ideas. The so-called dream-work must produce a visual representation of the dream-thoughts -- and dramatisation for Freud is the transformation of a thought into a visual situation. ${ }^{(12)}$ The relationship with the visual language of film is as present here as it is vague. After all, Freud never mentioned cinema in his many writings on art, and he refused categorically to take part in the making of Pabst's Geheimnisse einer Seele (1926), the first film on psychoanalysis. On the other hand, as Baudry has noticed, in Die Traumdeutung Freud described the psychic apparatus by comparing it to a microscope or a camera, thus indirectly recognising its analogy with optical devices. ${ }^{(13)}$

Besides Freud's reference to the dreams' visual language, relevant considerations can be found in the work of other psychoanalysts. For Jung, dreams develop according to an authentic dramatic structure, formed by a phase of exposition, in which setting and characters are presented; by a development of the plot; by a culmination or peripeteia, containing the decisive event; and by a lysis or solution. ${ }^{(14)}$ Interestingly enough, according to Jung the latter can be absent, when the unconscious mind is unable to propose a solution to the conflict -- almost a postmodern narrative lacking an ending.

Salomon Resnik also has described dreams as dramatic structures, made up of various acts, which are not always clearly linked, and can even take place simultaneously. ${ }^{(15)}$ Those acts are perhaps identifiable with the series of detached oneiric episodes that Cesare Musatti has said to be comparable to filmic sequences. ${ }^{(16)}$

Structured like a drama, thus, the dream stages the oneiric thoughts. Melanie Klein described the unconscious itself as a mental theatre, a stage on which the characters of our inner world perform. In his Psychoanalytic Studies Of the Personality (1952), Fairbairn went beyond his mentor and compared the characters of a dream to film actors. The dreamer is at the one time director, spectator and main character of his or her dream. To be more specific, the dreamer narcissistically plays all the roles, even when he or she has the sensation of being a simple spectator of the oneiric show. From a Freudian perspective, this is hypocrisy on the part of the dreamer, a defence used in order to avoid feeling responsible for the dream's contents. The same hypocrisy can be found in the cinematic spectator, who feels safe and innocent while, at the same time, identifying with the various characters, and therefore fulfilling her or his unspoken desires. The dreamer who, while asleep, is contemporaneously director, actor, and spectator, when awake -- according to Resnik -- becomes an editor, who reorders and connects the various oneiric sequences according to a narrative structure. ${ }^{(17)}$

A further important reference to the relationship between dreams and film can be found in the psychoanalytical literature. In 1944 Ernst Aeppli noticed that the oneiric events take place in a luminous field, framed by a large dark space. ${ }^{(18)}$ The evident analogy with the cinema auditorium found confirmation in Bertam D. Lewin's research. According to the American analyst, dreams are projected onto a white screen, the 'dream screen', representing the idea of sleep itself, or better the desire of sleeping and, contemporaneously, the maternal breast, as the infant saw it when falling asleep, once sated. In two communications dated respectively 1946 and 1948, Lewin defined the dream screen as 'a special structure ... distinguished from the rest of the dream and defined as the blank background upon which the dream picture appears to be projected.'. ${ }^{(19)}$

Whereas some psychoanalysts suggested that a dream is like a film (and seemingly their patients often say 'dream' when talking about a film and vice-versa, with a revelatory Freudian slip), many film theorists proclaimed, inverting the terms, that a film is like a dream.

\section{The film is like a dream}

From Lacan onwards, dreams are considered as texts which carry messages and are positioned between a sender and a receiver: the dreamer and the analyst or, even better, the unconscious and the conscious, since a recounted dream is an entirely different text from the original one. Lacan set as an object of study for psychoanalysis the oneiric language, with its signifying codes and linguistic structures. Parallel considerations inaugurated the discourse of cinema semiotics, with Metz's famous article 'Le cinéma: langue ou language..(20) Following in Metz's footsteps, in an essay dated 1965 Pier Paolo Pasolini suggested that, despite not being a language, cinema succeeds in communicating thanks to its use of a common store of signs. Cinematic spectators can read films because they are already used to reading the visual reality surrounding them. Furthermore, 'in man, an entire world is expressed by means of significant images -shall we therefore propose, by analogy, the term "im-signs" (imsegni, i.e. image-signs). This is the world of memory and dreams. ${ }^{(21)}$ Memories and dreams, along with the cinematic image, are for Pasolini part of 
visual communication, which is a pre-morphological and pre-grammatical fact. Dreams, in this perspective, are a precursor of cinema: 'all dreams are a series of im-signs which have all the characteristics of the cinematic sequence: close-ups, long shots, etc'. ${ }^{(22)}$

Several film theorists seemed to agree with Pasolini's belief that films and dreams speak the same language, and went on to look for further analogies.

According to Freud, our wish to sleep tries to create a situation of complete narcissism, in order to eliminate the external stimuli that may disturb our sleep, among which are unconscious removed desires and preconscious day's residues. The latter are traces of thoughts, perceptions and feelings that accumulated in the psyche during daytime. In attempting to overcome the removed materials and day's residues, the desire to dream raises in the preconscious. Such desire uses precisely the preconscious residuals, choosing from among them those most suitable to be linked to the dreamer's unconscious desires. The day's residues are the basis on which all dreams are formed. Several film theorists found a relationship between them and the 'profilmic' -- that section of reality or of a cinematic set that is before the camera. Like the day's residues, the profilmic is subject to a preliminary selection; furthermore, it is somehow binding -- even if the set is built or adapted to the needs of the filmmakers, it always constitutes a limiting materiality. ${ }^{(23)}$

By means of the day's residues, according to Freud, the dream-wish gives voice to the removed unconscious materials, forming the latent content of a dream. The dream-work, which processes this content, has two functions: to dissimulate the unconscious desire in order to circumvent censorship, and to transform the oneiric thoughts into images. By means of the dream-work, the manifest content of the dream is formed. As early as 1957, Raymond De Becker noticed that what he called the manifest themes of a film are to be considered as signals or symptoms by which it is possible to retrieve the film's unconscious contents. ${ }^{(24)}$ In a similarly explicit manner, Metz has recognised the possibility of studying screenplays or even films as manifest texts, looking for 'less visible significations'. ${ }^{(25)}$ Metz has indicated that one should not expect to find another complete screenplay, hidden behind the manifest one. 'Dreams themselves have no latent meaning in this sense: there is no second dream beneath the dream, there is only one dream which is manifest and opens on to a never ending series of non-apparent significations'(26)

Also Raymond Bellour and Guy Rosolato asserted that films always have a latent content, which can be hidden to a varying degree. ${ }^{(27)}$ Proof of the existence of such content is to be found in the notion, proposed by Bellour, of blocage symbolique, a miniaturisation of the dynamic of the whole film that is supposedly present in each sequence of the same film. The Oedipus, according to the author, underlies the blocage symbolique. ${ }^{(28)}$

\section{Dream-work, film work}

The dream-work, which transforms the latent content into manifest content, is formed, according to Freud, by two psychic processes. The primary process, which uses mobile energy and is ruled by the pleasure principle, controls three activities: condensation; displacement; and considerations of representability or dramatisation. Because of the action of condensation on all the oneiric thoughts, two or more images can blend into one image, presenting characteristics that belong to each. The activity of displacement moves energy from one image to another, which replaces it. Condensation and displacement collaborate to make unintelligible the dream-thoughts, with the purpose of circumventing censorship. Finally, dramatisation chooses among the oneiric thoughts those which can be more aptly transformed into images (dramatised).

The second activity of the dream-work, the secondary process, is regulated by the reality principle, and uses fixed energy. Its duty is to accomplish the secondary elaboration, by filling the gaps due to condensation and displacement. Thanks to the secondary process, the manifest content becomes more similar to conscious thought.

Beyond the comparison that has often been made between dramatisation and shooting on the one hand, and secondary elaboration and editing on the other, Metz has rigorously studied the action of the primary and secondary processes in the filmic text in the fourth section of Le signifiant imaginaire.

Drawing on Lacan -- who recognised the emergence of the unconscious in each activity of human thought -- Metz has asserted the invalidity of a radical separation between primary process, seen as a peculiarly unconscious activity, and secondary process, as characterising preconscious and conscious. The two processes 
interact. Censorship does not separate them as an impenetrable barrier; on the contrary, it is an unstable border that is often crossed, the pressure point between primary and secondary. In addition, for Metz the distinction between psychoanalysis, science of the primary, and linguistics, science of the secondary, does not exist. He has, in fact, placed his work on the point of convergence of these two disciplines: psychoanalysis, which discovered through Freud the operations of displacement and condensation and through Lacan tied them to metonymy and metaphor; and post-Saussurrean linguistics, with its notions of paradigm and syntagm.

Before studying the filmic figures from the point of view of the primary and secondary processes, Metz has insisted on two points: first, that there are no secondary figures, but only figures which are secondarised to a greater or lesser extent; similarly, there are no primary figures, but only figures which have escaped secondary elaboration to varying degrees. Secondly, Metz has stressed that neither is metaphor identical to paradigm, nor metonymy to syntagm. Following Jakobson, he has claimed that similarity and contiguity can establish themselves both on the positional axis, that of the discoursive chain, and on the semantic axis, that of meanings. Syntagm and paradigm concern the positional axis, whereas metaphor and metonymy work on the semantic axis -- which Metz prefers to call referential axis. The cinematic figures of superimposition and cross-fade, for instance, are syntagmatic on the discoursive axis; on the referential axis, depending on the context, they are either metaphoric or metonymic, or even both at the same time. In general, cinematic montage is a syntagmatic operation, as it joins the elements in the discourse; but from the point of view of content, the different types of montage can be both metonymic and metaphoric.

Having elucidated the question of metaphor and metonymy, Metz has analysed the operations of the dreamwork in their relationship with film. Whereas condensation is most certainly metaphorical, being based on similarities which are first compared and then superimposed, displacement is metonymic, because it is based on similarities existing in the passage from one object to another. Metz has identified the presence of the displacement-metaphor 'whenever the filmic text, as it proceeds, enters into what is clearly a transitional action, connecting (displacing) one motif on to another', ${ }^{(29)}$ as in the cases of metaphoric montage, camera movements and optical devices (dissolve, wipe, etc.).

Insisting on the impossibility of compiling exhaustive and conclusive lists, Metz has suggested classifying filmic figures according to four criteria: -- the level of secondarisation; the prevalence of metaphor or metonymy; the predominance of condensation or displacement, or the balance between them; and, finally, whether they are paradigmatic or syntagmatic. The lap dissolve, for instance, is for Metz a secondary figure, because it is codified as a punctuation mark and is a point of passage between two images; but it is also primary, in the instant of superimposition between the two images. The cross-fade also oscillates between metonymy (association by contiguity) and metaphor (association by similarity or contrast); moreover, it mainly consists of a displacement (it being a slow movement from one image to another); but it is also condensation, in the instant in which the two images are superimposed. Finally, the cross-fade is a syntagmatic indicator which produces 'a simultaneous syntagm, in space (a variant of the superimposition) and a consecutive syntagm, in time, since the superimposition does not last, it is finally resolved into a succession'.(30)

Searching for an analytical model suitable for investigating the cinematic language, for his part Thierry Kuntzel has adopted that of the dream-work developed by Freud. For the author, in fact, the analogy between oneiric considerations of representability and filmic narration by images is evident. Like Metz, Kuntzel compares displacement to the camera movements because these displace the spectator's gaze, they move it from one scene to an other scene. ${ }^{(31)}$ Condensation can also be found in the film, possibly in the form of composite images, iconic motifs assembling a series of signals and meanings. In his textual analyses, Kuntzel is attentive to further primary elements, such as repetition and overdetermination. However, the film is a comprehensible and ordered discourse and such a result in the dream-work is due to secondary elaboration. The question, then, is to determine in what way these processes work in film; to understand how the film's signifying elements can be ordered by the logic of the plot, by the continuity of the sequence, and by the consistency of the scene, while, at the same time, being part of an other work.

To sleep or to watch a film

Many scholars who have written on Cinema \& Psychoanalysis have taken part in the aforementioned debate 
concerning spectatorship theory, which had been shaped by the contributions of Morin and Mitry, and had taken place chiefly on the pages of the Revue Internationale de Filmologie. ${ }^{(32)}$

Roland Barthes participated in Issue 23 of Communications with 'En sortant du cinéma', a short article endorsing the idea of the para-oneiric quality of cinematic spectatorship. ${ }^{(33)}$ Barthes stressed that, when leaving the cinema, spectators feel sleepy and drowsy as if they had just woken up. Such a 'cinematic situation', though, is not established during the projection; according to Barthes, it exists even before entering the auditorium, since the act of going to the cinema originates from a disposition, from a holiday. Perhaps for this reason, or because cinema preserves something of the prohibition from watching the primal scene, going to see a film is for Barthes an authorised but asocial practice, which meets with less approval than most other activities.

A society like ours, in which going to the cinema is not a compulsory practice, needs to fill the auditoriums in order to guarantee the reproduction of the institution, and must therefore make sure that the desire to see films raises spontaneously in the public. That is why, according to Metz, the institution always aims for the filmic pleasure, and tries to build a 'good object' by using certain psychic mechanisms: identification, voyeurism, and fetishism. ${ }^{(34)}$

Holiday from daily reality, place for the representation of the primal scene, and desire machine, cinema -according to many psychoanalysts and film theorists -- allows spectators to immerse themselves in a dreamlike world, in which their repressed desires find fulfilment. This conception of cinema has often been criticised on the basis that dreams are produced by the dreamer's unconscious, whereas film is not produced by the spectator. As early as 1948, though, Serge Lebovici in one of the first contributions ever to be published on Cinema \& Psychoanalysis wrote, 'the spectator doesn't choose his film any more than the dreamer chooses his dream'.(35) The dreamer, in fact, is a spectator of his or her dream. The sensation of being at the mercy of one's dream finds explanation in the Lacanian idea of the unconscious as discourse of the Other.

The question of the difference between oneiric hallucination and spectatorial perception has also been discussed from a psychoanalytic perspective. In Freudian terms, the images of a film are a stimulus which, from the outside, hits the perceptive extremity of the psychic system and, through consciousness, leaves a trace in memory (sometimes in the memory particular to the unconscious mind); in dreams, on the other hand, the excitation follows a regressive direction, from the unconscious to perception. According to Metz and others, the immobility and almost foetal position assumed by the spectator in the darkness and comfort of the auditorium create a regressive condition, in which the spectator exhibits a primitive behaviour and, impelled by the pleasure principle, hallucinates images. ${ }^{(36)}$ Metz has explained this hypothetical phenomenon by stating that the energy that has not been dispersed through motion regresses toward the perceptive organs, thus favouring the impression of reality. In dreams such an impression is stronger, and corresponds to an illusion of reality. For Metz, there are cases in which the spectator's cognition is closer to that of the dreamer; for instance, when the spectator is particularly tired or is absorbed by the narrative. The author also believes that spectatorship is close to that oneiric state in which the dreamer is aware of dreaming, and reassuringly reminds himself or herself that 'it's only a dream'.

According to Baudry, film is an artificial hallucinatory psychosis. ${ }^{(37)}$ The cinematic apparatus, in fact, presents the spectator with representations, which offer themselves as perceptions. Even more, it creates an impression of reality which has no comparison with the one provided by normal perception; in front of a film, one has the sensation of seeing something 'more than real'. For Baudry, it is not the film's imitation of reality, of varying precision, which creates the illusion, but the functioning of the apparatus itself. Spectators are like the prisoners in Plato's cave: they see only shadows which, moreover, are projected by statues, that is to say not by reality, but by a reproduction of reality. Analogously, by projecting shadows cinema creates the same 'more than real' effect that is experienced in dreams. Baudry also subscribes to the belief that the typical conditions of the cinematic situation (the spectator's passivity and immobility, the lack of the reality proof, and the darkness of the auditorium) are the reasons why the cinematic apparatus almost creates a hallucination. Even more, he believes that the functioning of the cinematic apparatus faithfully reproduces that of the sleeping psychic apparatus.

Forgetting and analysing

Oblivion is one of the main components of the phenomenon of dreaming, and an important aspect of dream 
analysis. Many people do not remember their dreams at all, so much so that they do not believe they have an oneiric life. Research on REM sleep seems instead to indicate that we all dream at least four or five times per night.

Various explanations for people's tendency to forget their dreams have been put forward; from a psychoanalytic perspective, there seems to be two main reasons. The first resides in the structure of the unconscious mind; once we wake up, it is difficult for us to reconstruct the dream, which depends on logic criteria so different from those regulating the conscious thought. The second reason is that forgetting is a form of resistance, of repression of the painful unconscious contents; in short, we forget because we do not want to remember.

According to Raymond Bellour, films, like dreams, are particularly susceptible to oblivion, more so than other art forms. ${ }^{(38)}$ For the author, the explanation might reside in the almost oneiric condition that the spectator lives at the cinema: the film, partly dreamt, is forgotten because of the same mechanisms of repression that are active when we dream.

The idea that we forget films more easily than novels or sculptures for me has yet to be proved; if a useful analogy can be found here, it is that, when analysing either dreams or films, we do not work on the actual text, as we do for instance in the cases of a novel or a painting, but on a second, different text.

The interpretation of a dream is carried out on the patient's report of a memory of that dream or, even worse, on the notes of that narration that the analyst took. When we analyse a film we are not confronted with the same text that we saw at the cinema, in the unalterable flow of the projection; but with a series of episodes, sequences, images, codes and figures, which we arbitrarily select, group and replay various times, sometimes in slow-motion.

There is, of course, a tangible difference between dreams and films: in the work of art the unconscious symbolism is, unlike in dreams, permanently represented. Nevertheless, as Bellour has pointed out, there are in a film images of which the spectator catches a glimpse, more than clearly sees; these are almost oneiric images since, when we want to capture and freeze them by improperly breaking the film's flow, we can no longer find them, or better we transform them into something different. ${ }^{(39)}$

The existence of such images, which we see only during the projection of the film, and not when viewing it frame by frame, forces us to recognise that in films there can be obscure areas, which resist analysis and cannot be explored. Similar areas seem to exist in dreams. When Freud confronted the question of interpretation in its relation to oblivion, he suggested that often in dreams there is an obscure point, which must go unexplored. 'This is the dream's navel, the spot where it reaches down into the unknown'(40)

\section{Is the dream metaphor useful?}

Each of the contributions on Cinema \& Psychoanalysis that are summarised above are based on Freudian theories. This is so because the father of psychoanalysis produced the most authoritative and complete model for the interpretation of dreams, later enriched by the contributions of Jacques Lacan and Melanie Klein. Consequentially, non-Freudian psychoanalytical approaches to film and dream which can be found in the literature are less satisfactory. Francesco Salina, for instance, has used Ignacio Matte Blanco's conclusions on the functioning of the unconscious mind to analyse Hitchcock's Dial M For Murder. ${ }^{(41)}$ Sandro Bernardi, adopting a similar perspective, read the genre of melodrama as an example of cinema of 'infinite sets'. ${ }^{(42)}$ Because of the predominance of the Freudian approach, the theoretical apparatus resulting from the debate is rather compact, and can be criticised as a whole. I would argue that the principal positive outcome of these writings is the important contribution that they made to our awareness that films are the product of a work -- and therefore of an industry, as well as of a (patriarchal) society. On the other hand, by stating that films fashion and control our subconscious, and that we consume them driven by our desire to elude reality, these writings led to a theoretical impasse, which has been difficult to surmount.

The cited articles, in fact, are based on the connected ideas of the passivity of the spectator and of the negative duplicity of the filmic image. Cinema is described as a deceptive mirroring of reality, because of its impressive, dream-like realism. The negative connotation of this duplicity probably arises from the prejudice against vision diffuse in many western cultures, a prejudice that considers vision to be an illusory and deceiving activity. The myth of Plato's cave, with its corollary of visual fallacy, not accidentally occupies 
a significant place in those writings. ${ }^{(43)}$ Such an approach to the filmic image implies the idea of a dangerous detachment from reality on the part of the spectator, a detachment that has been variously considered as consoling escapism or as an instrument of ideological and subliminal control of the masses.

One of the strongest ideas to come out of these writings is that of the passivity of the spectator, who is said to assume an almost foetal position in the darkness and comfort of the auditorium. This idea is easily refuted. Firstly, an uncomfortable or technically poor auditorium presents viewing conditions that would hardly allow the described regression. Secondly, there are various ways of watching a film, most of which are not comparable with the one described by the promoters of the metaphor of film as dream. Much cinema is now consumed through television, which often produces a fragmentary, distracted, and interrupted viewing activity, for instance by advertisements, zapping, food, and the telephone. Videorecorders, laser disks, DVDs or similar media offer the same viewing conditions as television, with the addition of the distancing effects produced by fast forwarding and frame freezing. Finally, contemporary films constantly remind us that we are at the cinema, by recycling and quoting from other films or cultural products.

Furthermore, such a tendency towards regression is not an obvious occurrence, even in a beautifully comfortable cinema where a classical film is projected. Spectators normally do not hallucinate, unless in very particular physical and emotional conditions. Even if we remain a step shorter and say with Baudry that they 'almost' hallucinate, I would argue that spectators never completely forget that they are at the cinema. Certainly, they can also suspend this knowledge; they can believe in the filmic images and be deeply affected by them; they can strongly identify with characters and situations and project their secret desires and fears on the screen. This does not mean, though, that spectators are completely subjugated and at the mercy of the filmic discourse. They always know that they are watching a film, and not reality; it is the degree of this consciousness that varies -- the border between credence and mistrust, perception and illusion is, in fact, unstable and often crossed, whether voluntarily or not.

I believe that our authors (unnecessarily) forced their description of the spectator's situation to match that of the dreamer. This was compounded by a misrepresentation of the Freudian dreamer, who is not passive and at the total mercy of his or her unconscious mind. In a brief but italicised passage of The Interpretation of Dreams, which has often been forgotten, Freud wrote that 'throughout our whole sleeping state we know just as certainly that we are dreaming as we know that we are sleeping.(44) Dreamers, like spectators, know that what they are watching is not reality, but the projection of images on a screen (Lewin's dream screen).

Even so, the Cinema \& Psychoanalysis debate, by comparing filmic, perceptive and oneiric images, improved our understanding of the cinematic situation; furthermore, it had the merit of highlighting the presence of a hidden, subconscious side to films and to spectatorship. This positive result was also reached through debates and contributions that no longer take centre stage. In particular, Metz's analysis of the filmic figures from the perspective of the primary and secondary processes has had the merit of revealing how the unconscious (of the filmmaker, of the film?) has a role to play, for instance in the transitional moments between one image and the next. On the other hand, the example of Metz's analysis of the cross fading, which can be described as both primary and secondary, metonymy and metaphor, displacement and condensation, shows the limits of such enterprises.

I would suggest that the metaphor of the dream could still be useful in film analysis, rather than in the construction of a general and comprehensive theoretical apparatus. Some of our authors approached specific texts in the framework of the couple Cinema \& Psychoanalysis -- for instance, Thierry Kuntzel analysed Fritz Lang's $M^{(45)}$ and Shoedsack and Pichel's The Most Dangerous Game. ${ }^{(46)}$ More recent examples include a reading of Vertigo as an Oedipal dream; ${ }^{(47)}$ a Freudian analysis of Resnais' Providence; ${ }^{(48)}$ a study of the dream imagery in Tarkovsky; ${ }^{(4)}$ and a study of the dream-like characteristics of musical videos. ${ }^{(50)}$ These useful although dissimilar articles testify to a successful practice and attest the validity of the employment of the dream metaphor in the analysis of appropriate films.

\section{Notes}

1. Christian Metz, Le signifiant imaginaire. Psychanalyse et cinéma (Paris, Union Générale d'Editions, 1977), En. trans.: The Imaginary Signifier. Psychoanalysis and the Cinema, trans. by Celia Britton, 


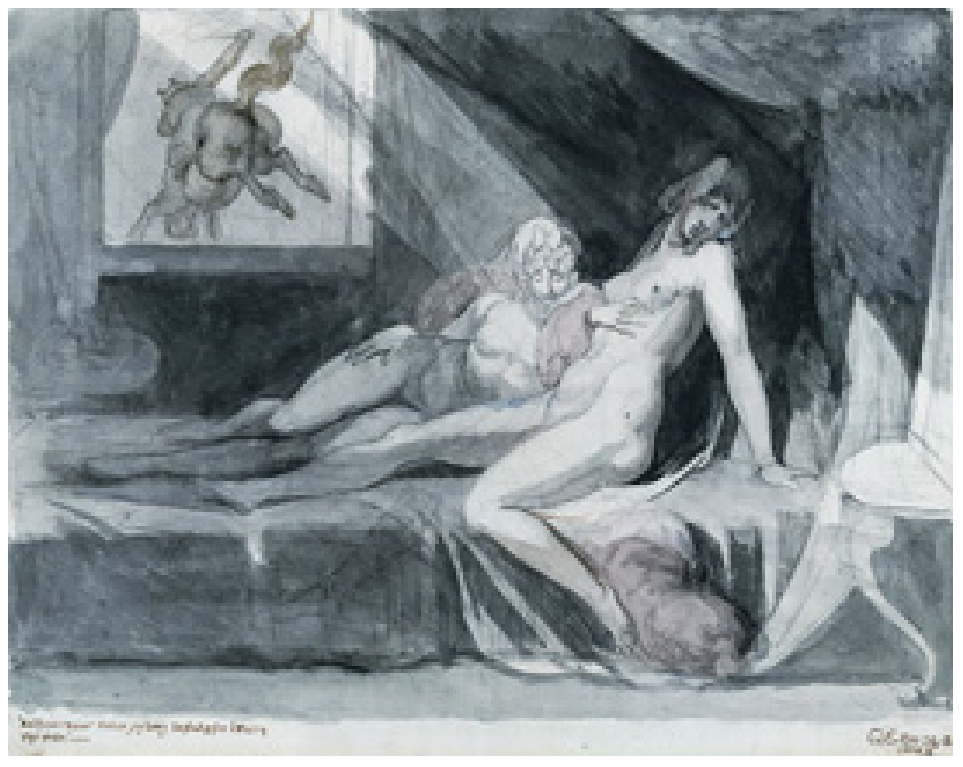

Figure 1: Nightmare: Incubus leaving two sleeping women (Johann H. Fussli, 1810)

Annwyl Williams, Ben Brewster and Alfred Guzzetti (Bloomington: Indiana University Press, 1982), pp. $17-21$.

2. Francesco Casetti, Theories of Cinema 1945-1990 (Austin: University of Texas Press, 1999), pp. 159-160.

3. Marie Bonaparte, Edgar Poe. Sa vie, son oeuvre. Etude analytique (Paris, PUF, 1958).

4. For instance, cf. Charles Mauron, Des métaphores osédantes au mythe personnel (Paris: Librairie José Corti, 1963).

5. Henri Agel, Esthetique du cinéma (Paris: Presses Univ. de France, 1957).

6. André Breton, Comme dans un bois (1951), in Gianni Rondolino, L'occhio tagliato. Documenti del cinema surrealista e dadaista, (Turin: Martano, 1972), pp. 89-92.

7. René Clair, Reflexion faite (Paris: Gallimard, 1951).

8. And many others, among which: Lotte Eisner, Die daemonische Leinwand (Frankfurt: FischerTaschenbuch-Verl., 1980); Antonin Artaud, A propos du cinéma (Paris: Gallimard, 1961); and Stan Brackage, Metaphors of Vision (New York: Film Makers' Coop., 1963).

9. Also Antonin Artaud spoke about the dreamlike qualities of the American burlesque, a genre which was beloved by the Surrealists. Cf. Artaud, cit., p. 22.

10. Edgar Morin, 'Nouveau courants dans la culture de masse', in Istituto 'Agostino Gemelli' per lo studio sperimentale di problemi sociali dell'informazione visiva (Milan, 1966), pp. 258-269.

11. Odile Bächler, 'Images de film, images de rêve; le véhicule de la vision', CinémAction, 50 (1989), pp. 40-46.

12. Sigmund Freud, Ueber den Traum (1901), En. trans. On Dreams, in The Standard Edition of the Complete Psychological Works of Sigmund Freud (London: The Hogarth Press, 1978), v. 5, pp. 654-658.

13. Jaen-Luis Baudry, L'effet cinéma (Paris: Albatros, 1978), p. 13.

14. Carl Gustav Jung, Vom Wesen der Träume (1945-1948), En. trans. On the Nature of Dreams, in The 
Collected Works of C.G. Jung (London: Routledge \& Kegan Paul, 1977), v. 8, pp. 281-297.

15. Salomon Resnik, Il teatro del sogno (Turin: Bollati Boringhieri, 1982).

16. Cesare Musatti, Libertà e servitù dello spirito. Diario spirituale di uno psicoanalista 1945-1971 (Turin: Bollati Boringhieri, 1971), p. 83.

17. Salomon Resnik, 'Pensiero visivo, rito e pensiero onirico', in V. Branca, C. Ossola and S. Resnik (eds.), I linguaggi del sogno (Florence: Sansoni, 1984), p. 53.

18. Ernst Aeppli, Der Traum und Seine Deutung (Zürich: Eugen Rentsch, 1944).

19. Bertram D. Lewin, 'Inferences from the dream screen', International Journal of Psychoanalysis, vol. XXIX, 4 (1948), p. 224. The first article published by Lewin on the dream screen is: 'Sleep, the mouth and the dream screen', The Psychoanalytic Quarterly, vol. XV (1946). Robert T. Eberwein extensively referred to Lewin's dream screen in his Film and the Dream Screen (Princeton: Princeton University Press, 1984).

20. Christian Metz, 'Le cinéma: langue ou langage', Communications, 4 (1964), pp. 52-90.

21. Pier Paolo Pasolini, 'Il cinema di poesia' (1965), En. trans.: 'The Cinema of Poetry', in Bill Nichols (ed.), Movies and Methods (Berkeley-Los Angeles-London: University of California Press, 1976), pp. 542-558.

22. Pasolini, cit., p. 544.

23. Cf., for instance, Pierre Sorlin, 'Tournage et montage: les fantasmes de la réalisation', CinémAction, 50 (1989), pp. 26-32.

24. Raymond De Becker, 'Pour une psychanalyse du cinéma', Table Ronde, 109 (1957), pp. 79-89.

25. Christian Metz, The Imaginary Signifier, cit., p. 28.

26. Ibid.

27. Raymond Bellour and Guy Rosolato, 'Dialogue: se (ce) souvenir d'un film', Hors Cadre, Spring 1983, pp. 150-167, En. transl.: 'Dialogue: Remembering (this memory of) a film', in E. Ann Kaplan, Psychoanalysis E6 Cinema (New York-London: Routledge, 1990), pp. 198-216.

28. Raymond Bellour, 'Le blocage symbolique', Communications, 23 (1975), pp. 235-250.

29. Metz, cit., p. 271.

30. Metz, cit., p. 278.

31. Thierry Kuntzel, 'Le travail du film', Communications, 19 (1972), pp. 25-39.

32. On the role played by psychology in the approach to film of French filmology cf. Edward Lowry, The Filmology Movement and Film Study in France (Ann Arbor, Michigan: UMI Research Press, 1982).

33. Roland Barthes, 'En sortant du cinéma', Communications, 23 (1975), pp.104-107.

34. Metz, cit., p. 7-8.

35. Serge Lebovici, 'Psychanalyse et cinéma', Revue Internationale de Filmologie, 281 (1948), p. 53 (my translation).

36. Metz, cit., p. 113-119.

37. Louis Baudry, 'Le dispositif: approces metapsychologiques de l'impression de réalité', Communications, n. 23 (1975), pp. 56-72.

38. Raymond Bellour and Guy Rosolato, 'Dialogue: se (ce) souvenir d'un film', cit.

39. 'L'image s'est désormais fixée autrement, entre mobile et immobile, a la fois sur l'écran réel et l'écran mental don't elle dépend', Raymond Bellour, 'L'entretemps', author's manuscript, X Convegno di Studi sul 
Cinema e gli Audiovisivi, Urbino, 5-7 July 1991, p.1.

40. Freud, Die Traumdeutung, cit., p. 525.

41. Francesco Salina, 'Mystery Tales e Mystery Tools (Appunti per una bi-logica filmica)', in Edoardo Bruno, Per Alfred Hitchcock (Montepulciano: Editori del Grifo, 1981), pp. 181-184.

42. Sandro Bernardi, 'Il cinema come insiemi infiniti', Filmcritica, 332 (1982), pp. 98-105.

43. Jean-Louis Baudry, 'Le dispositif: approches métapsychologiques de l'impression de réalité', cit., pp. $56-72$.

44. Sigmund Freud, Die Traumdeutung, En. trans. The Interpretation of Dreams, in The standard edition of the complete psychological works of Sigmund Freud (London: Hogarth, 1953), vol. 5, p. 571.

45. 'Le travail du film', cit.

46. 'Le travail du film, 2', Communications, 23 (1975), pp. 136-189.

47. James F. Maxfield, 'A Dreamer and His Dream: Another Way Of Looking At Hitchcock's Vertigo', Film Criticism, 3 (Spring 1990), pp. 3-13.

48. Diane L. Shoos, 'Language and Repression in Alain Resnais' Providence', Film Criticism, 3 (Spring 1989), pp. 3-12.

49. Vlada Petric, 'Tarkovski's Dream Imagery', Film Quarterly, v. 43, 2 (Winter 89/90), pp. 28-34.

50. Gary Burns, 'Dreams and Mediation in Music Video', Wide Angle, v. 10, 2 (1988), pp. 41-61.

\section{Author Information}

Laura RASCAROLI is Toyota Lecturer in Film and Media Studies at the National University of Ireland, Cork. Her principal research interest lies in Film Theory. She is currently co-writing a book on Postmodern Cities in European Cinema with Dr Ewa Mazierska of Manchester Metropolitan University (UK). She has published on Screen and Enculturation. 